${ }^{\odot}$ Entomologica Fennica. 7 July 1998

\title{
Redescriptions of three Meyricks Asiatic elachistid species, with descriptions of two new species (Lepidoptera, Gelechioidea)
}

\section{Lauri Kaila}

Kaila, L. 1998: Redescriptions of three Meyrick's Asiatic elachistid species, with descriptions of two new species (Lepidoptera, Gelechioidea). - Entomol. Fennica 9: 53-63.

Elachista heteroplaca Meyrick, Ptilodoxa lorigera Meyrick and Platyphyllis leucosyrma Meyrick are redescribed. Elachista albrechti sp. n. (Nepal) and Elachista planicara sp. n. (Kuriles) are described. E. heteroplaca, P. lorigera, $E$. albrechti and E. planicara are assigned to a species group related to the Elachista (Cosmiotes) freyerella group. Platyphyllis leucosyrma is placed in the Elachista tetragonella group. The genera Ptilodoxa and Platyphyllis Meyrick are considered to be synonyms of Elachista Treitschke (syn. n.). A lectotype is designated for E. heteroplaca.

Lauri Kaila, Finnish Museum of Natural history, P.O. Box 17, FIN-00014 University of Helsinki, Finland; e-mail: Lkaila@cc.helsinki.fi.

Received 8 July 1997, accepted 23 December 1997

\section{Introduction}

The currently accepted generic classification (see e.g. Parenti 1996, Hodges 1998) of the world-wide distributed Gelechioidean family Elachistidae (s. str.) is largely a product of historical tradition and has been heavily influenced by the relatively well-known West-Palaearctic fauna. New materials from other regions of the world, however, contain species that cannot readily be placed in the established genera or species groups. Therefore, there is a current need for a revised generic classification that is based on a rigorous analysis of the phylogeny of the group on a world scale.

Most species of Elachistidae reported from outside the Holarctic region were described by E. Meyrick during the late 1800 s and early 1900 s. A majority of the species and genera described by him occur in Africa, India, Australia and New
Zealand. His original descriptions contain no illustrations, nor are there any references to the taxonomically highly informative genital characters. Clarke (1964, 1970), Parenti $(1972,1988)$ and Kaila $(1996,1997)$ have illustrated some of Meyrick's species of Elachistidae. However, many of his taxa still remain intact, and thus their identity and systematic status is virtually unknown.

The aim of this paper is to contribute to the classification of the Elachistidae by providing redescriptions for three of Meyrick's less-known species that are of particular interest in the light of the phylogeny of the family. I also include descriptions of two new species related to Meyrick's species. Statements of the phylogenetically informative characters and the systematics of the taxa are based on my analysis of the phylogeny of Elachistidae s. str., which will be published separately (Kaila in prep.). 


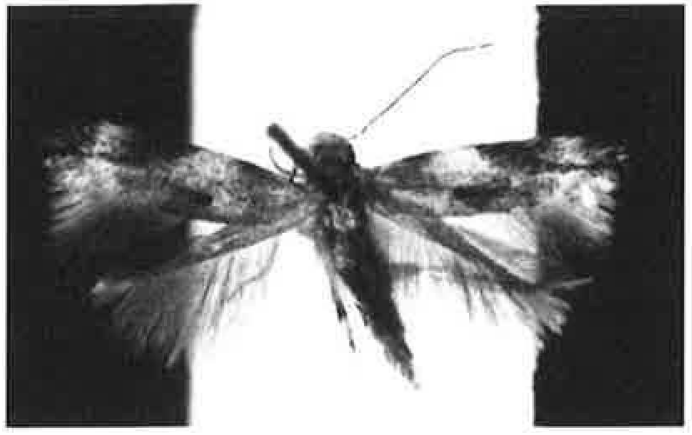

Fig. 1. Elachista heteroplaca Meyrick ơ lectotype.

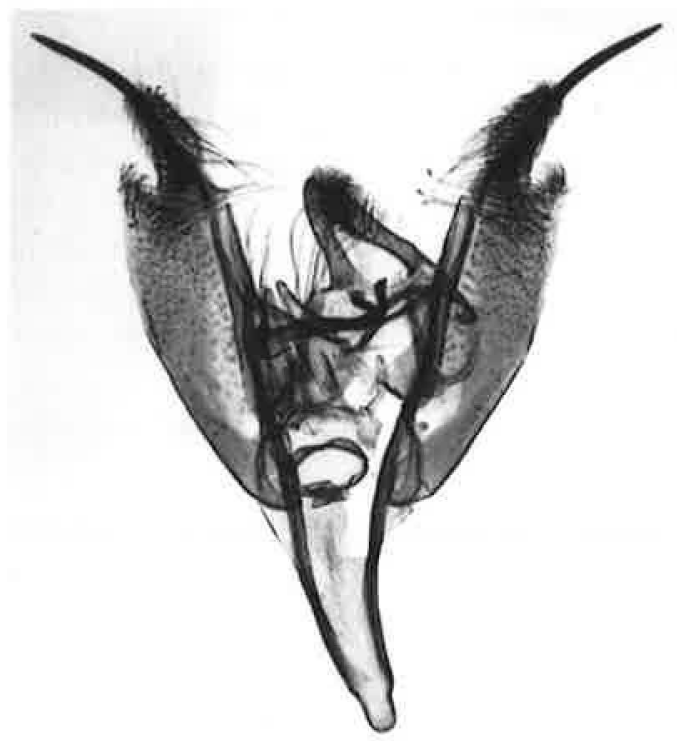

Fig. 2. Elachista heteroplaca Meyrick ơ genitalia (lectotype, B.M. 28 577), aedeagus removed.

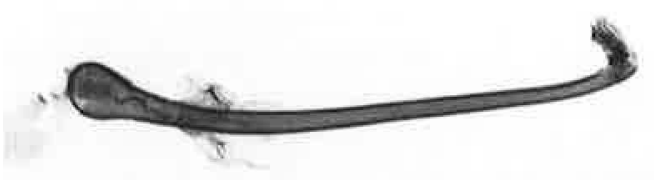

Fig. 3. Elachista heteroplaca Meyrick of aedeagus (lectotype, B.M. 28 577).

The terminology follows Traugott-Olsen and Nielsen (1977) with additions explained in Kaila (1997).

\section{Abbreviations}

BIN - Biological Institute, Russian Academy of Sciences, Novosibirsk, Russia (V. V. Dubatolov).

BMNH - Department of Entomology, The Natural History Museum, London, U.K. (K. R. Tuck).

RMNH - Nationaal Natuurhistorische Museum, Leiden, The Netherlands (E. J. van Nieukerken).

ZMH - Zoological Museum, Finnish Museum of Natural History, Helsinki, Finland (L. Kaila).

\section{The species}

\section{Elachista heteroplaca Meyrick}

Figs. 1-5

Elachista heteroplaca Meyrick, 1934: 528.

Type material examined. - Lectotype ơ (here designated) labelled: Lecto- $\mid$ type $\mid$ rounded label with blue margin]; Shillong I Assam I TBF 10.5.[19]28; Elachista | heteroplaca | 1/1 Meyrick I Meyrick det. I in Meyrick Coll.; heteroplaca Meyr. B. M. ơ | Genitalia slide I No. 28577. (In Coll. BMNH).

Paralectotype ơ: Khasis; $5000 \mathrm{ft}$. I Shillong | 9.v.1923 Fletcher Coll.; COTYPE | Elachista | heteroplaca | Meyr. 1934 [all white]. (In Coll. BMNH). Both specimens in good condition

Diagnosis. - Elachista heteroplaca (Fig. 1) is a small-sized and peculiarly coloured species which is externally readily distinguished from other elachistid species, except Elachista lorigera and E. planicara (see below) by the oblique, dorsoventrally depressed head, which resembles that of some species in the New World genus Periploca Braun (Cosmopterigidae) (cf. Fig. 10). The male genitalia of $E$. heteroplaca (Fig. 2) are very distinctive with their bilobed valval cucullus and the long curved spine in the distal fold of the costa. According to the external appearance, $E$. heteroplaca is close to, if not conspecific with, $E$. lorigera, which is presently only known from the female holotype. Therefore, the status of $E$. heteroplaca cannot be evaluated until the male of $E$. lorigera is discovered.

Description $\left(\mathrm{O}^{7}\right)$. - Labial palpi upwards curved and strongly diverging, length twice the diameter of the head, shiny whitish. Head very oblique, shiny whitish, neck tufts light brownish grey. Scape of antenna whitish; flagellum without visible ciliation, grey, weakly annulated with 
darker grey; basal 1/3 whitish below. Thorax light brownish grey. Legs pale below, leaden grey above, tibia and tarsal articles with pale distal rings. Forewing: ground colour light brownish grey, costa dark grey except in the middle where large indistinctly delimited white patch that almost reaches fold, and at distal 3/4 where triangular indistinct whitish spot; in the middle of wing at fold black spot formed of long raised scales; tornal area whitish; narrow longitudinal black stripe to apex of wing; apex slightly upturned. Cilia grey, except in distal $3 / 4$ of costa and at tornus largely creamy, along termen blackish. Hindwing grey, cilia apically white. Underside of wings grey. Forewing length $2.9 \mathrm{~mm}$.

Male genitalia: Uncus lobes widely apart from each other, lobes basally twisted so that the densely scaled ventral surface is almost turned to dorsal side; lobes narrow, elongate and blunt-tipped. Basal arms of gnathos basally strongly sclerotised, black; spinose knob small, rounded. Anterior margin of tegumen dorsomedially strongly indented, almost meeting posterior margin. Costa of valva almost straight; from distal fold of costa long curved strongly sclerotised spine, length of which half of that of valva. Cucullus divided into two lobes: a small triangular lobe where sacculus meets cucullus, and another larger lobe in costal side. Digitate process narrow, slightly bent, blunttipped, distally setose. Median plate of juxta with dorsally directed posteriolateral pockets. Juxta lobes medially produced, median margin straight and distinctly sclerotised, distal margin straight with long scales. Vinculum very long, v-shaped; saccus short blunt-tipped. Aedeagus narrow, basally dilated, weakly bent, with one small hornshaped and another larger, elongate, folded cornutus.

Systematics. - The male genitalia of E. heteroplaca are highly modified in respect to several structures, particularly in valva. The genitalia have, however, characters in common with Elachista and related genera, such as the digitate process and the concave median plate of the juxta. Elachista heteroplaca belongs to a clade comprising species currently placed in the genera Dicranoctetes Braun, Eupneusta Bradley and Cosmiotes Clemens. These genera have synapomorphies in common with the Elachista bifasciella group (= Elachista s. str.), such as the modified shape of tergum 8 (see Fig. 5), the small and strongly

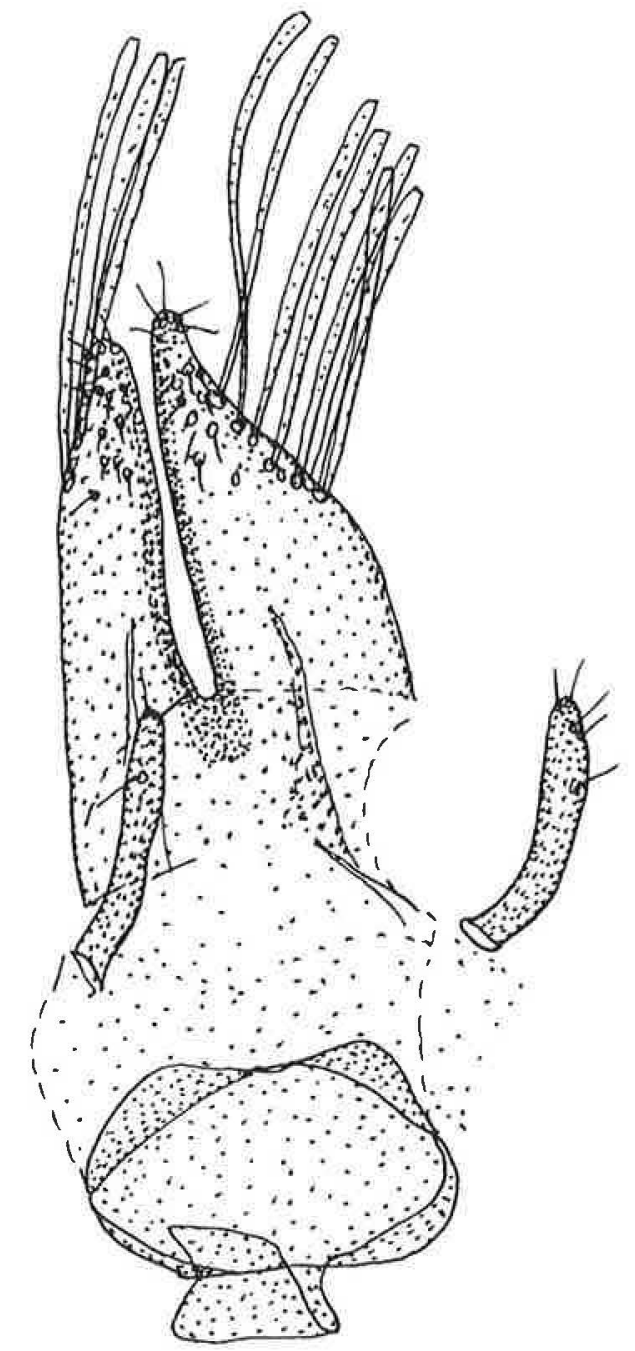

Fig. 4. Elachista heteroplaca Meyrick ơ genitalia, details of juxta and digitate process (lectotype, B.M. 28577 ).

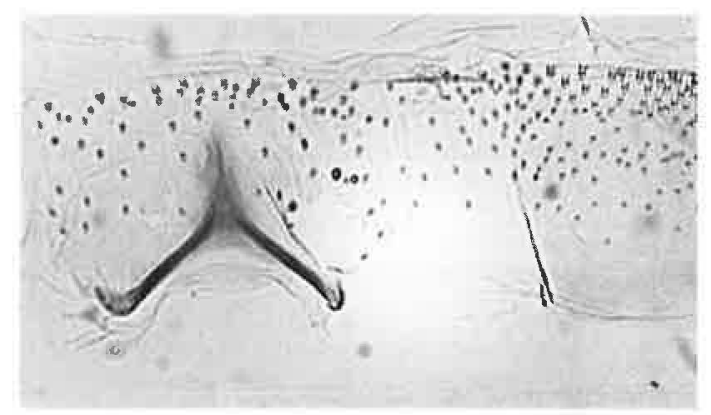

Fig. 5. Elachista heteroplaca Meyrick ơ tergum 8 (lectotype, B.M. 28 577). 


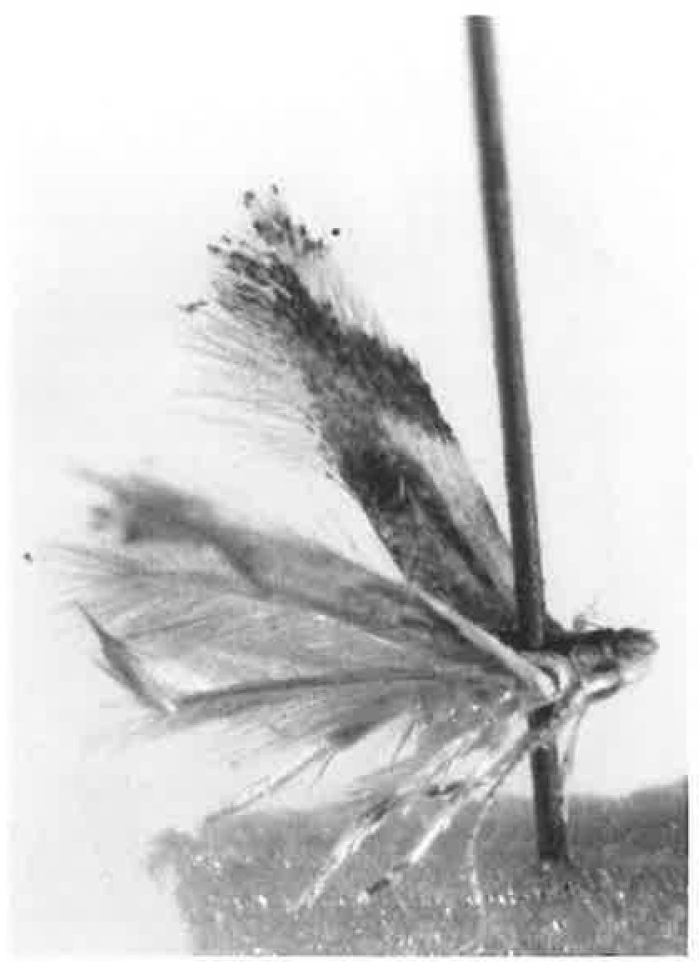

Fig. 6. Elachista lorigera (Meyrick) 9 holotype.

sclerotised distal lobe of the valval costa, the longitudinal fold in the ventral surface of the valva forming the "hump" in the costa, ventral surface of uncus lobes covered with elongate scales, dorsally projected lateral pockets in the median plate of the juxta (further modified in many Cosmiotes). The species placed in these genera share as further synapomorphies the dorsally strongly indented anterior margin of the tegumen, the twisted uncus lobes and the reduction of the hindwing vein M2, and several characters in the pupal morphology. For reasons discussed further in connection with the phylogeny of the family, the assigning of all these species groups to the genus Elachista is to be anticipated.

\section{Elachista lorigera Meyrick comb. $\mathbf{n}$.}

Figs. 6 and 7

Ptilodoxa lorigera Meyrick, 1921: 186.

Type material. - Holotype 9 , labelled: 22; M251; Java I Pekalongan | v Deventer [all white, with handwriting];

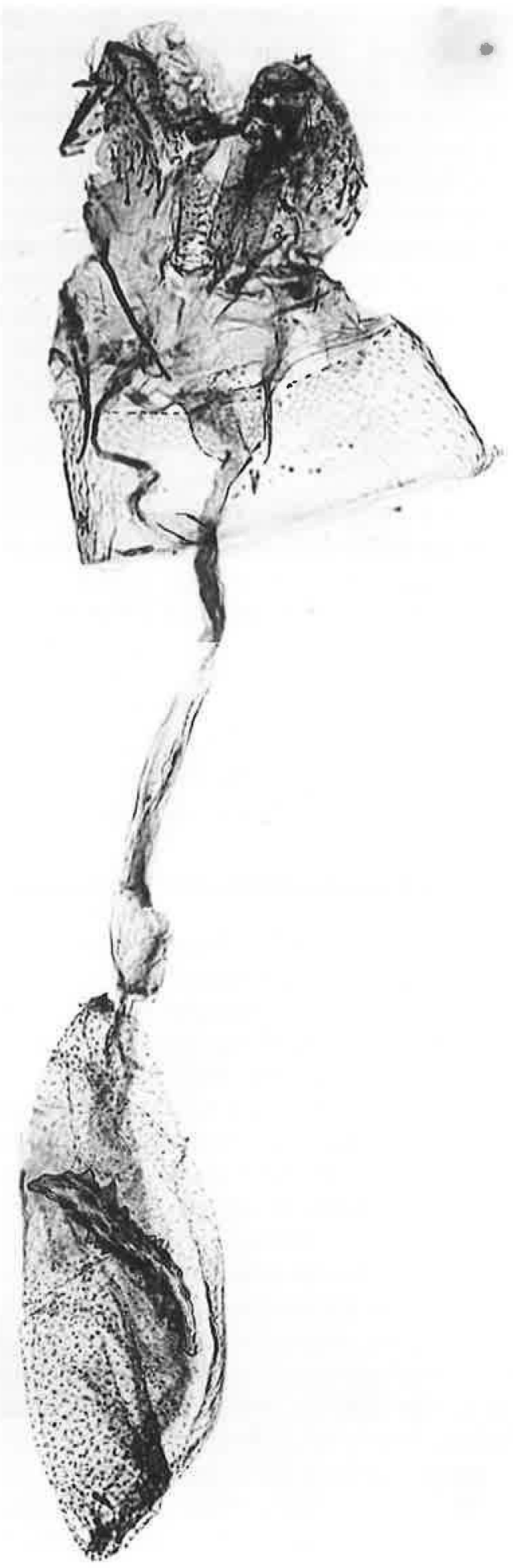

Fig. 7. Elachista lorigera (Meyrick) $\subsetneq$ genitalia (holotype, LK 2617). 
TYPE [green]; lorigera I Meyr.; Ptilodoxa Meyr. [both folded collection labels]; Museum Leiden I HOLOTYPE I Ptilodoxa | lorigera | Meyrick, 1921 [red]; L. Kaila | prep. no 2617.

Diagnosis. - The species is externally close to Elachista heteroplaca (see diagnosis of the species above).

Description (O) - Labial palpi upwards curved and strongly diverging, length 1.7 times the diameter of the head, shiny whitish above, third segment powdered with fuscous below. Head very oblique, shiny whitish, neck tufts light, powdered with brown. Scape of antenna whitish; flagellum without visible ciliation, pale, annulated with darker grey above. Thorax light brownish grey, powdered with brown. Legs pale, tibia and tarsal articles distally dark above. Forewing: ground colour brownish grey, costa narrowly dark grey except in the middle where large indistinctly delimited white patch that almost reaches fold, and at distal $3 / 4$ where long oblique white streak that is extended to apex; in the middle of wing at fold dark grey spot formed of raised scales. Cilia grey, except in distal $3 / 4$ of costa and at tornus largely creamy. Hindwing grey, cilia apically white. Underside of wings grey. Forewing length $2.7 \mathrm{~mm}$.

Female genitalia: Papillae anales rather small, broad semicircular, basally weakly sclerotised. Apophyses slightly winding, apophyses posteriores twice longer than apophyses anteriores. Ostium bursae situated in integument between sternum 7 and the hardly sclerotised sternum 8 . Antrum almost quadrangular, anteriorly abruptly narrowing into straight ductus bursae; ductus bursae 3.5 times longer than apophyses anteriores, membranous; ductus seminalis inserted to ductus bursae at anterior margin of sternum 7. Corpus bursae oval, covered with rough internal spines; signum large, elongate, broadest medially, irregularly dentate.

Systematics. - Ptilodoxa lorigera shares with $E$. heteroplaca and E. planicara (see below) the very oblique head, which is otherwise unique within Elachistidae. Moreover, the peculiar wing pattern of $P$. lorigera is similar to that of $E$. heteroplaca, even so that the possibility that these taxa could be conspecific cannot be excluded. Further support for the placement of these species in the same species group comes from the structure of the female genitalia of $P$. lorigera. The species has a similar large wine glass-shaped sclerotised

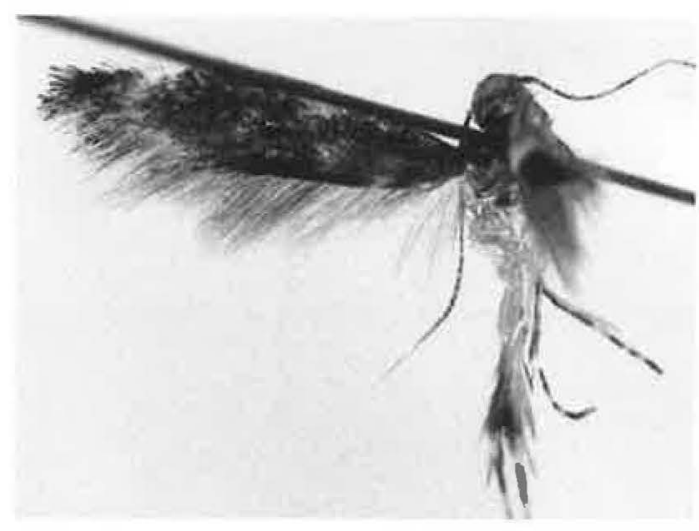

Fig. 8. Elachista planicara sp. n. 9 holotype.

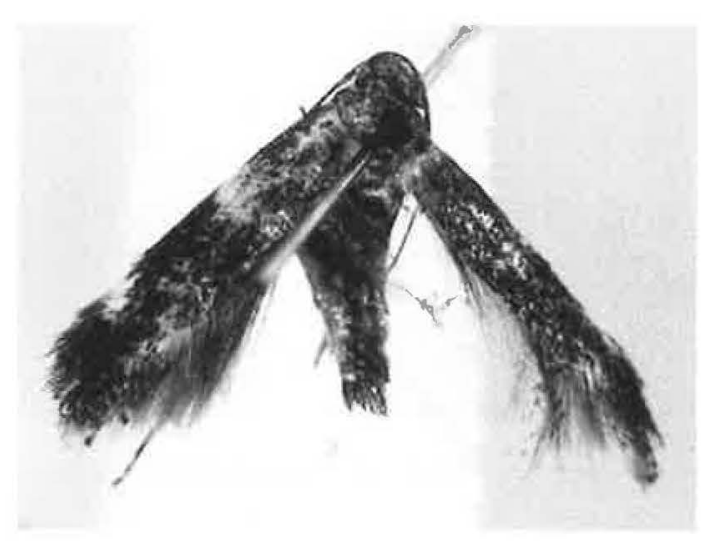

Fig. 9. Elachista planicara sp. n. ㅇ paratype (Kuriles, Kunashir Is.).

antrum, and the ostium bursae is situated in the integument between sterna 7 and 8, alike in the species currently placed at the genus Dicranoctetes. On the basis of this evidence, supplemented with the notions presented above under the diagnosis and systematics of $E$. heteroplaca, I associate Ptilodoxa lorigera Meyrick in the same species group with Elachista heteroplaca and therefore consider the monotypic genus Ptilodoxa a junior subjective synonym of Elachista Treitschke, syn. $\mathbf{n}$.

\section{Elachista planicara sp. n.}

Figs. 8-11

Type material. - Holotype \&: Kuriles, Ins. Kunashir, Ivanoskiy, 3.VIII.1989 V. Dubatolov, V. Zinchenko \& 


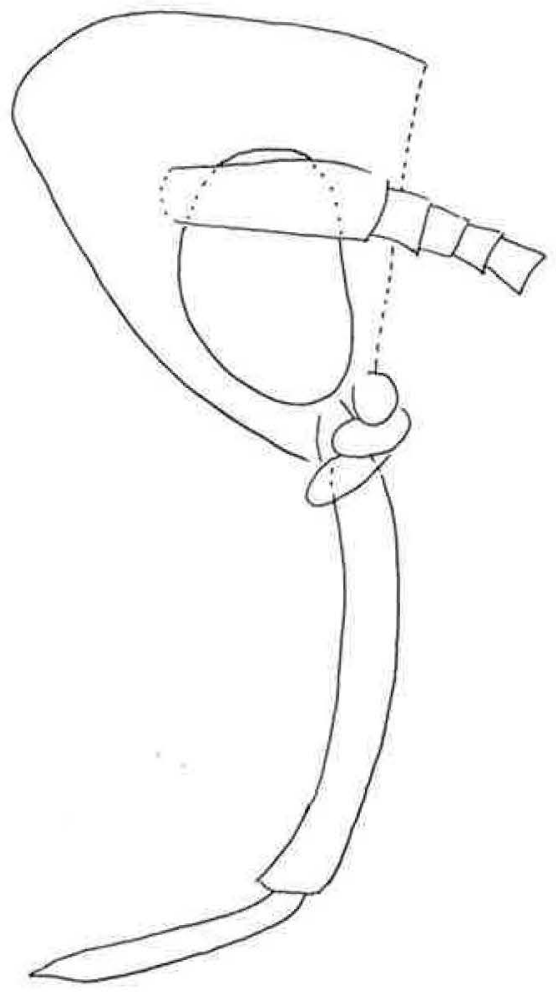

Fig. 10. Elachista planicara sp. n., head in lateral view.

O. Rusanov leg. L. Kaila prep. no. 1517. (In Coll. BIN). Paratype $1 \&$ with the same collecting data as in holotype. (In Coll. ZMH). Both specimens are in good condition, although not spread.

Diagnosis. - Elachista planicara is a rather large dark grey species with a transverse fascia in the middle, and a triangular costal and another tornal spot near apex forming the light pattern of the forewings. As such, the species resembles the numerous representatives of the Elachista bifasciella group. The species is, together with E. heteroplaca and E. lorigera (see above), characterised by the very oblique head (Fig. 10) that distinguishes them from all other elachistids. E. planicara is readily distinguished from the other species by the dark grey ground colour and larger size, assuming no sexual dimorphism among the species. It should be noted that among the related groups sexual dimorphism exists in the species of the $E$. freyerella group. In these species the females are more brightly coloured and the contrast between the light and dark pattern in the wings is

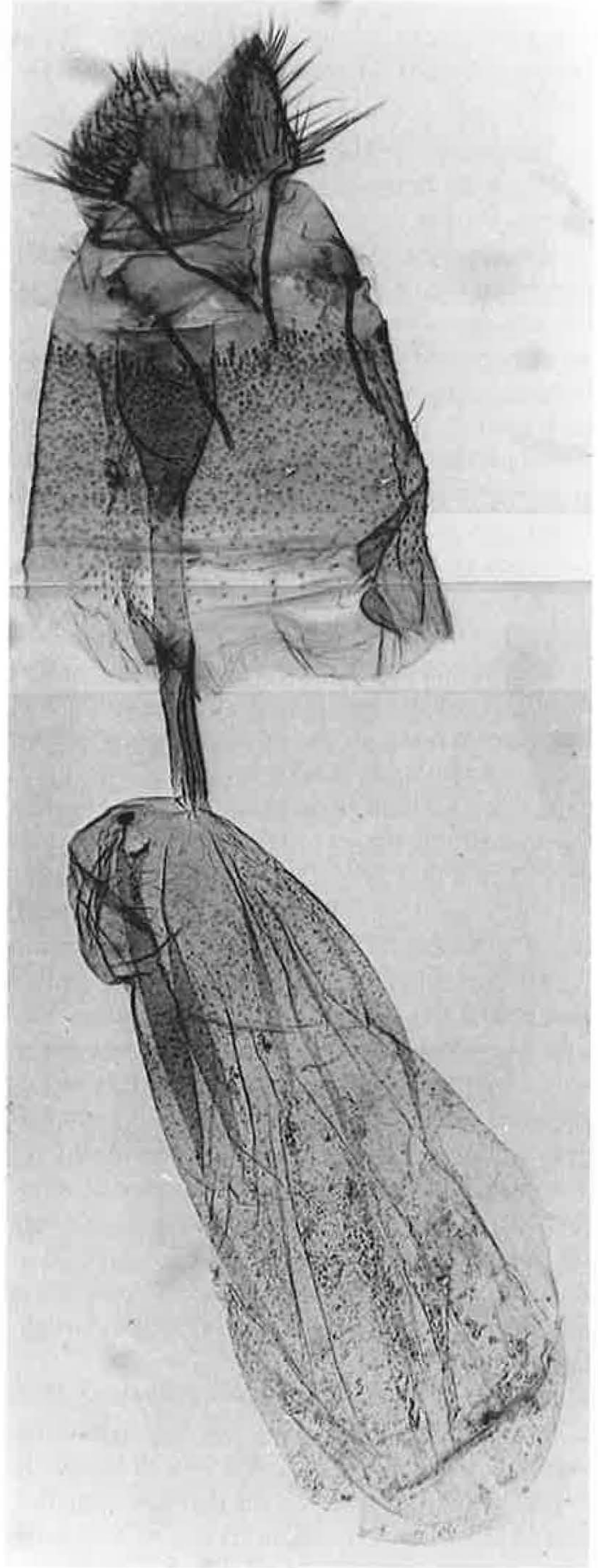

Fig. 11. Elachista planicara sp. n., female genitalia (holotype, LK 1517).

more pronounced in females than in the dull-coloured males. Therefore, it is highly improbable 
that the specimens here described as E. planicara could actually be females of either $E$. heteroplaca or E. albrechti.

Description (\$). - Labial palpi upwards curved and strongly diverging, length more than twice the diameter of the head, pale ochreous. Head very oblique, pale ochreous below, leaden grey above. Antenna leaden grey, articles distally annulated with dark grey. Thorax and patagium leaden grey. Legs pale ochreous, except hindtibia and tarsal articles medially leaden grey. Forewing: ground colour grey with slight brownish tinge, densely mottled by largely dark grey scales; before middle transverse, medially constricted light grey fascia; on dorsal side of fold, apical to fascia a blackish spot formed of raised scales; in distal 3/4 of costa triangular light grey spot, another similar spot situated opposite to it at tornus; along termen transverse lines formed of regularly arranged long scales which are basally bluish white and distally blackish. Cilia grey. Hindwing grey, underside of wings dark grey. Forewing length 4.7-4.9 mm.

Female genitalia: Papillae anales rather small, broad semicircular, basally weakly sclerotised. Apophyses slightly winding, rather stout, apophyses posteriores a little longer than apophyses anteriores. Ostium bursae situated in the integument between sternum 7 and the hardly sclerotised sternum 8 . Antrum very large, wine glass-shaped, distally parallel-sided, anteriorly narrowing into short and straight ductus bursae; posterior half of ductus bursae membranous, anterior half with internal longitudinally folded sclerotization; ductus seminalis inserted in the middle of ductus bursae. Corpus bursae large, elongate oval, sparsely covered with minute internal spines; no signum.

Systematics. - Elachista planicara shares with $E$. heteroplaca and $E$. lorigera the very oblique head, which is otherwise unique within Elachistidae. Further support for the placement of these species in the same species group comes from the structure of the female genitalia of E. planicara. The species has similar large wine glass-shaped sclerotised antrum, and the ostium bursae is situated in the integument between the sterna 7 and 8, alike in the species currently placed at the genus Dicranoctetes. As discussed above, the male genitalia of $E$. heteroplaca have several features in common with those of that group.

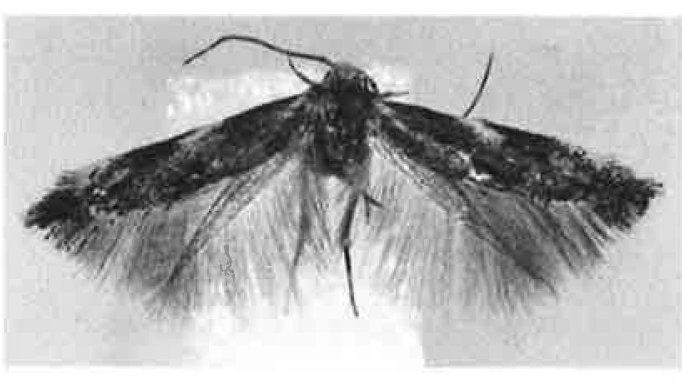

Fig. 12. Elachista albrechtisp. n. $0^{\top}$ holotype.

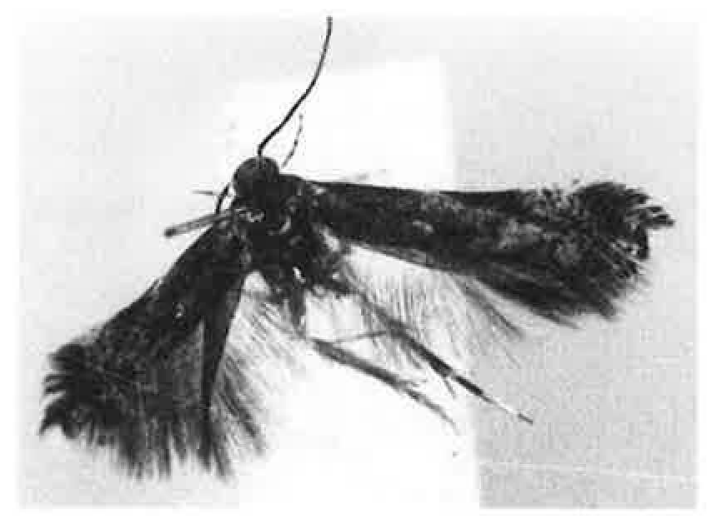

Fig. 13. Elachista albrechtisp. n. o" paratype (Nepal, Mt. Pulchoki).

Remarks. - As E. planicara is the third species with the distinctive form of head, I chose to describe the species although the male is unknown.

\section{Elachista albrechti sp. n.}

Figs. 12-17

Type material. — Holotype $0^{\prime}$ : Nepal $27^{\circ} 35^{\prime} \mathrm{N} 85^{\circ} 25^{\prime} \mathrm{E} \mathrm{Mt}$. Pulchoki, 2700 m, 10.V.1996 Exp. A. Albrecht, O. Biström, K. Mikkola \& A. Wikberg leg. Paratypes: 20 with the same collection data as in holotype, and $10^{\circ}$ with the same data except the altitude $2500 \mathrm{~m}$. One of the paratypes preserved in glycerol. (All in coll. ZMH.)

Diagnosis. - Elachista albrechti is a mediumsized species of Elachistidae with a somewhat varying forewing pattern (Figs. 12 and 13). The male genitalia (Figs. 14 and 15) of the species are very distinctive with peculiarly shaped gnathos, long and winding aedeagus and particularly with the distally broadened and bilobed valva. As such, 


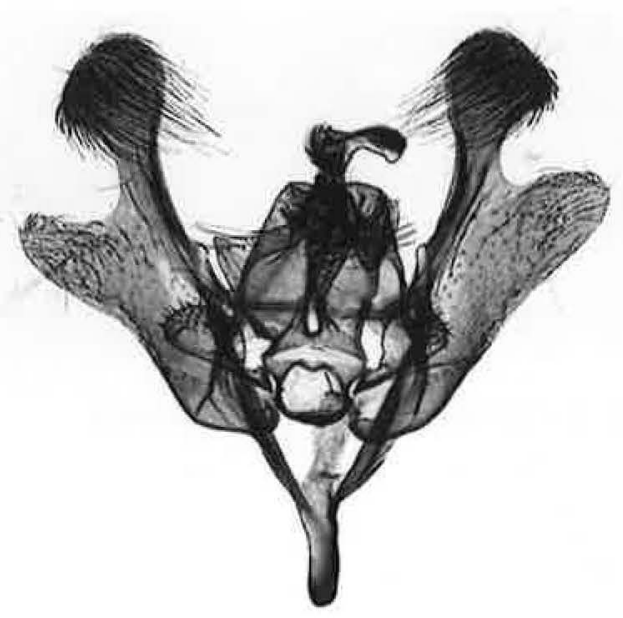

Fig. 14. Elachista albrechtisp. n. O' genitalia (holotype, LK 2530).

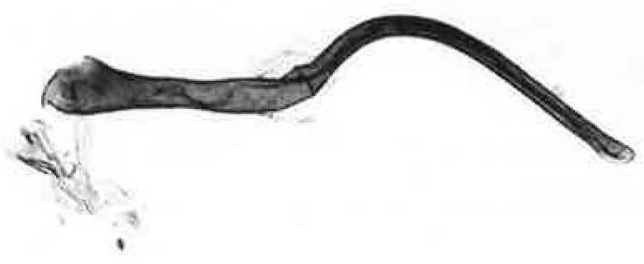

Fig. 15. Elachista albrechti sp. n. $\sigma^{7}$ aedeagus (holotype, LK 2530).

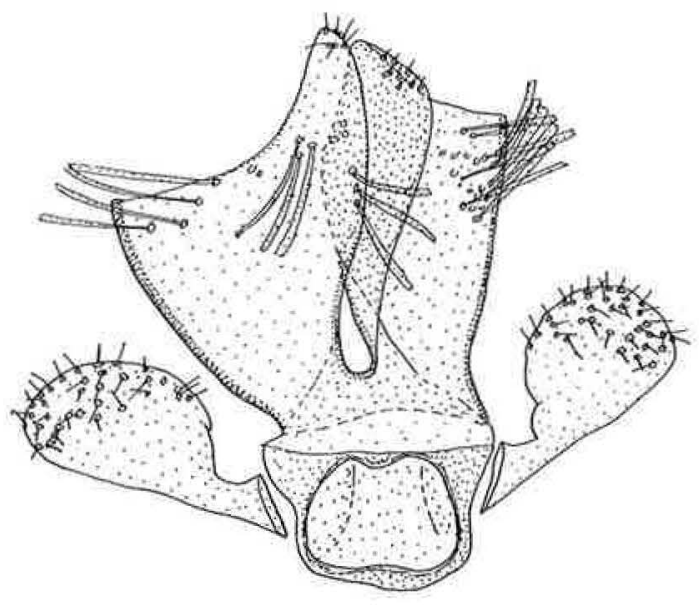

Fig. 16. Elachista albrechti sp. n. o' genitalia, details of juxta and digitate process (holotype, LK 2530).

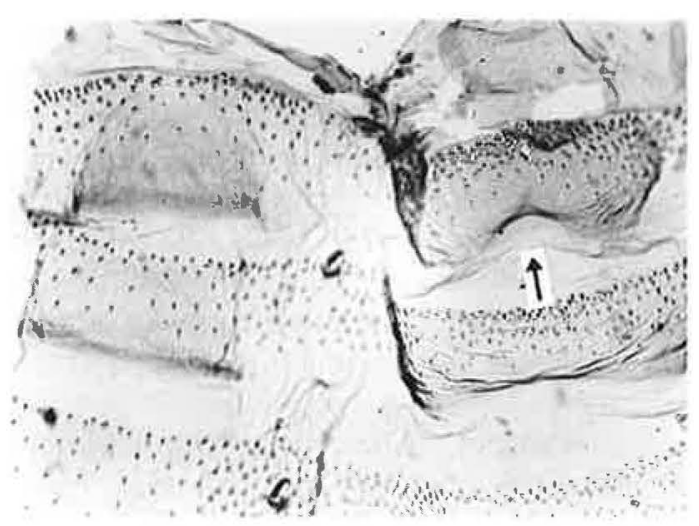

Fig. 17. Elachista albrechti sp. n. ơ abdominal segments, tergum 8 marked with an arrow.

the species cannot be mixed with any other known species.

Description (0 ). - Labial palpi upwards curved and strongly diverging, length twice the diameter of the head, pale ochreous; maxillary palpi entirely reduced. Head pale ochreous, slightly darker above; lateral ocelli present. Antenna unicolorous grey, without visible ciliation. Thorax leaden grey, patagium distally ochreous. Legs pale below, leaden grey above; tibia and tarsal articles with pale distal rings. Forewing: ground colour varying from creamy to a mixture of rusty and dark grey scales, costa dark grey except medially from where oblique pale ochreous streak nearly extends to fold, and in distal $3 / 4$ where it is creamy to varying extent; before middle of wing at fold black spot formed of long raised scales; in some specimens narrow longitudinal black stripe to apex of wing; apex slightly upturned. Cilia in distal $3 / 4$ of costa largely creamy, along termen blackish with small white apical spot, otherwise leaden grey. Hindwing and underside of wings leaden grey. Forewing length 4.1-4.2 mm. Wing venation: Forewing with four $\mathrm{R}$-veins, $\mathrm{CuA} 2$, $\mathrm{CuA1}$, M2 and M1, cell closed; hindwing with $\mathrm{RS}$ and M1 long stalked; CuA2, CuA1 present, M2 absent.

Male genitalia: Uncus lobes widely apart from each other, lobes basally twisted so that the densely scaled ventral surface is almost turned to dorsal side, tongue-shaped, relatively small, slightly longer than their width. Basal arms of gnathos basally strongly sclerotised, black, spinose knob 
distally indentated, spinose areas separated by membranous area. Anterior margin of tegumen dorsomedially almost meeting posterior margin. Valva broad; costa almost straight, basal fold of costa meets distal fold at $1 / 4$ from base; cucullus enormously enlarged, medially broadly indentated and thus divided into two lobes. Digitate process club-shaped, distal dilation large, rounded or slightly elongate, setose. Median plate of juxta with shallow lateral pockets. Juxta lobes very large, cusp-shaped, medially produced as curved horn, distal margin otherwise straight, medially with long scales, meeting the straight lateral margin in sharp angle. Vinculum tapered into long tube-shaped saccus. Aedeagus very long and narrow, basal and distal thirds almost straight, median 1/3 strongly twisted and curved; no cornuti.

Systematics. - According to the distally bilobed cucullus of valva, the twisted uncus lobes, the juxta lobes with long scales, and the very thickly sclerotised and distally coalescent basal arms of gnathos, Elachista albrechti is a relative of $E$. heteroplaca Meyrick (for further details, see above).

\section{Elachista leucosyrma (Meyrick) comb. n.} Figs. 18-21

\section{Platyphyllis leucosyrma Meyrick, 1932: 216.}

Type material examined. - Holotype \%, labelled: HoloI type [rounded label with red margin]; Khasi Hills, I Assam. | 1925; Platyphyllis | leucosyrma | 4/5 Meyrick | E. Meyrick det. I in Meyrick Coll.; PLATYPHYLLIS Meyr.; leucosyrma Meyr.; B. M. ㅇ I Genitalia slide INo. 28550 [all white]. (In Coll. BMNH).

Diagnosis. - Elachista leucosyrma (Fig. 18) is a fairly small and broad-winged species. The forewings are dark grey with two indistinct lighter bluish grey fasciae across the forewings. The female genitalia (Figs. 19 and 20) are typical for the species of the Elachista tetragonella group with the shallow, bowl-like and parallel-sided antrum that is anteriorly abruptly narrowed, leaving a narrow membranous zone between the antrum and the sclerotised colliculum. The very small and indistinct signum (Fig. 21) consists of a weakly sclerotised and irregularly formed plate that laterally contains one tooth.

Description. - Labial palpi 1.3 times the diameter of the head, diverging and upwards curved;

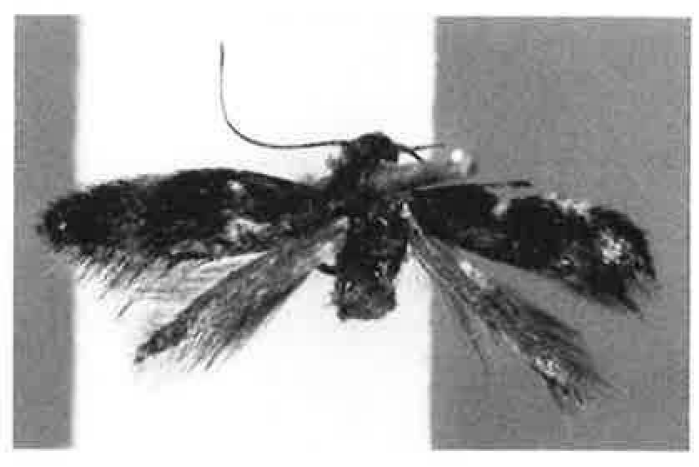

Fig. 18. Elachista leucosyrma (Meyrick) $\subsetneq$ holotype.

unicolorous grey. Head and neck tufts shiny leaden grey. Antenna grey with short visible ciliation. Thorax and patagium grey. Foreleg unicolorous grey [other legs missing]. Forewing broad, ground colour dark grey; before middle very indistinct lighter bluish grey fascia, another, medially outwardly angled fascia of same colour at $2 / 3$ of wing, formed of medially confluent costal and tornal spots. Cilia unicolorous grey. Hindwing and underside of wings grey. Forewing length $3.7 \mathrm{~mm}$.

Female genitalia: Papillae anales relatively large [the distal part of the papillae anales of the type are missing due to pest damage]; apophyses distally weakly curved, apophyses anteriores and apophyses posteriores of equal length. Ostium bursae situated in anterior margin of sternum 8; antrum sclerotised, parallel-sided bowl-shaped, abruptly narrowed into ductus bursae; a short membranous part situated between antrum and sclerotised colliculum. Ductus bursae long and narrow, posterior third weakly sclerotised up to insertion point of ductus seminalis; ductus bursae gradually broadened as rounded corpus bursae; corpus bursae sparsely covered with minute internal spines; signum weakly sclerotised and irregularly formed curved elongate plate, with one prominent tooth laterally.

Systematics. - Platyphyllis leucosyrma is known only from the female holotype from Assam, India. The female genitalia of $P$. leucosyrma have a similar form of antrum as the species of the Elachista tetragonella group, as redefined in Kaila (1996). The antrum of these species is bowlshaped, posteriorly shortly parallel-sided, anteriorly abruptly narrowed. Between the antrum and 


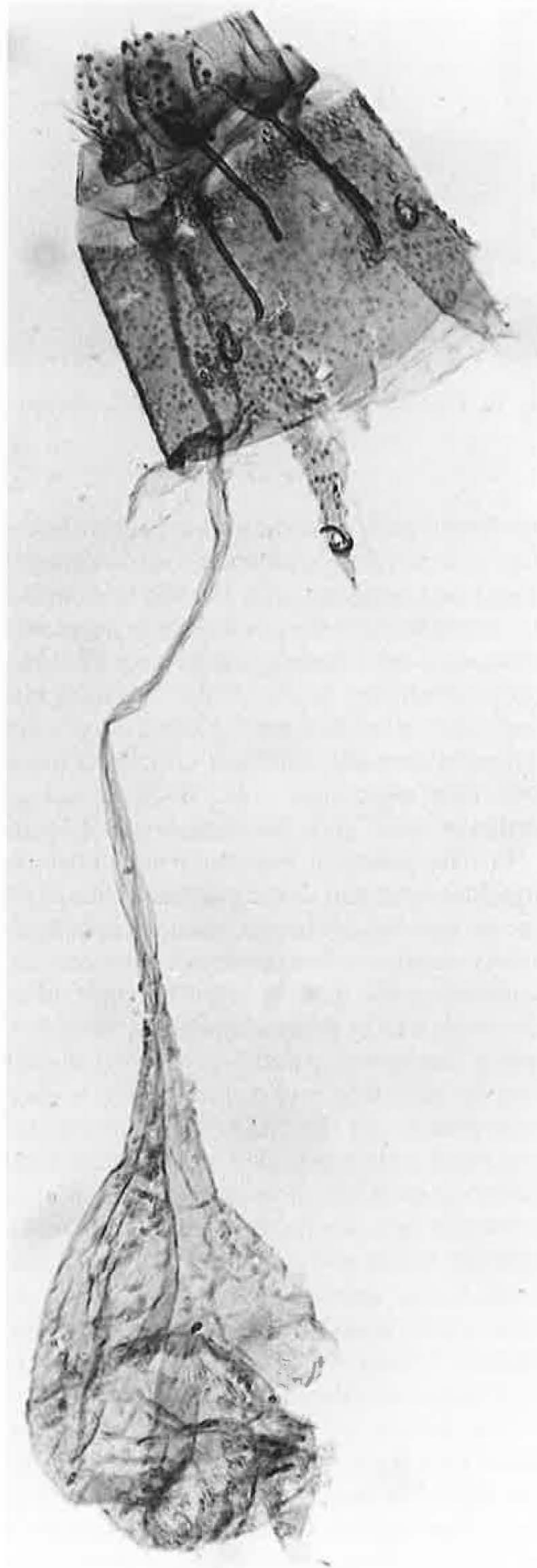

Fig. 19. Elachista leucosyrma (Meyrick) 9 genitalia (holotype, B.M. 28 550).

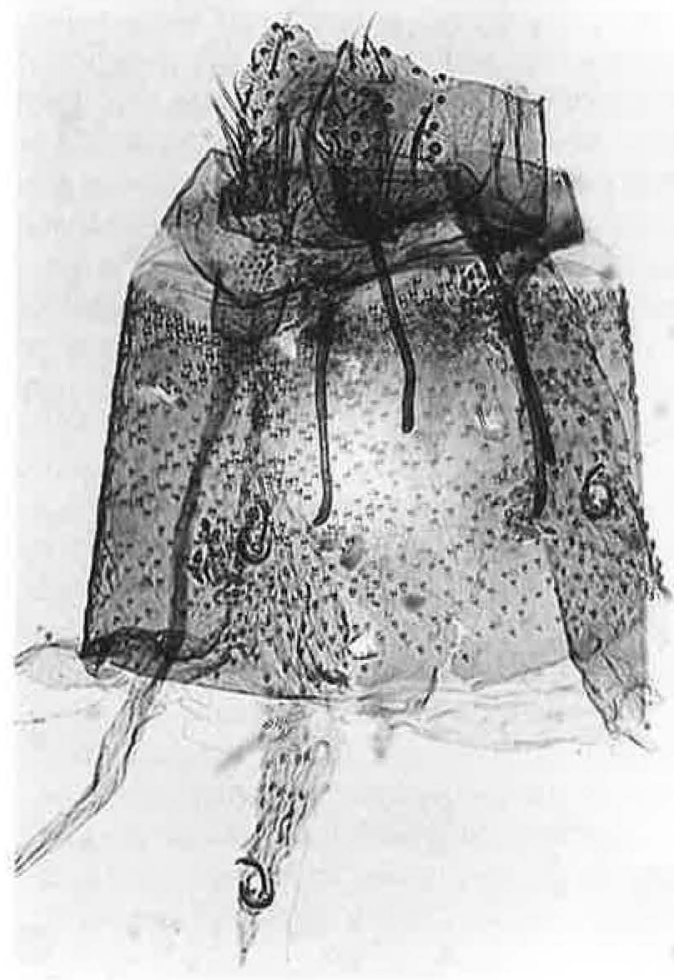

Fig. 20. Elachista leucosyrma (Meyrick) $ᄋ$ genitalia, region of ostium bursae (holotype, B.M. 28 550).

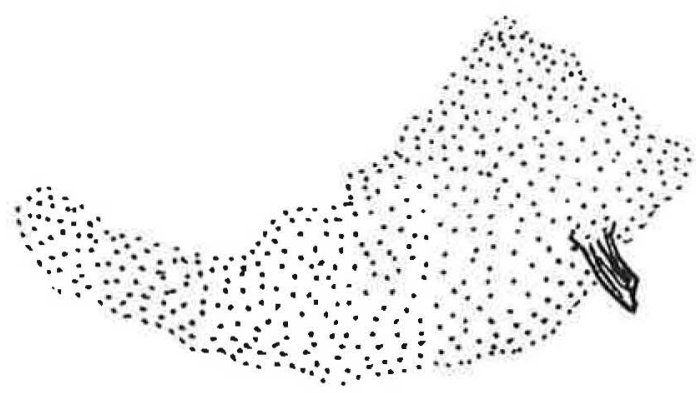

Fig. 21. Elachista leucosyrma (Meyrick) 9 genitalia, signum of corpus bursae. (holotype, B.M. 28550 ).

the sclerotised colliculum there is a short membranous part in the ductus bursae. Based on this evidence, and in the absence of any disagreeing characteristics, I associate Platyphyllis leucosyrma Meyrick in the Elachista tetragonella group and therefore consider the monotypic genus Platyphyllis a junior subjective synonym of Elachista Treitschke, syn. n. 
Remarks. - In BMNH there are two further specimens $\left(10^{\prime} 1\right.$ O $)$ that are collected from Java and identified as $P$. leucosyrma by Meyrick. These specimens are not, however, conspecific with the holotype of $P$. leucosyrma, but represent a probably undescribed species that is, according to the structure of male genitalia, related to Elachista abiskoella Bengtsson.

Acknowledgements. V. Dubatolov (BIN), E. J. van Nieukerken $(\mathrm{RMNH})$ and $\mathrm{K} . \mathrm{R}$. Tuck $(\mathrm{BMNH})$ allowed me to examine valuable specimens. R. Talman and R. Tyynelä helped me with processing photographs. K. P. Bland and J. Itämies gave valuable comments on the manuscript, and $\mathrm{H}$. Fullenwider improved my language. I thank all of them.

\section{References}

Clarke, J. F. G. 1964: Catalogue of the type specimens of Microlepidoptera in the British Museum (Natural History) described by Edward Meyrick. Vol, 4, - London. $521 \mathrm{pp}$.

Clarke, J. F. G. 1970: Catalogue of the type specimens of Microlepidoptera in the British Museum (Natural History) described by Edward Meyrick. Vol. 8. - Lon- don. 261 pp.

Hodges, R. W. 1998: The Gelechioidea. — In: Kristensen, N. P. (ed.), Lepidoptera: moths and butterflies. Handbook of Zoology/Handbuch der Zoologie 1. Berlin \& New York. (In press.)

Kaila, L. 1996: Revision of the Nearctic species of Elachista I. The tetragonella group (Lepidoptera, Elachistidae). - Entomol. Scand. 27: 217-238.

Kaila, L. 1997: Revision of the Nearctic species of Elachista II. The argentella group (Lepidoptera, Elachistidae). Acta Zool. Fennica 206: 1-93.

Meyrick, E. 1921: New Micro-Lepidoptera. —Zool. Meded. (Leiden) 6: 145-202.

Meyrick, E. 1932: Exotic Microlepidoptera IV: 216-219.

Meyrick, E. 1934: Exotic Microlepidoptera IV: 528.

Parenti, U. 1972: Revisione degli Elachistidi (Lepidoptera, Elachistidae) paleartici. I. I tipi di Elachistidi del Museo di Storia naturale di Parigi. - Boll. Mus. Zool. Univ. Torino 2: 29-56.

Parenti, U. 1988: About some African and Asiatic species of the family Elachistidae (Lepidoptera) described by E. Meyrick. - Stapfia 16: 185-198.

Parenti, U. 1996: Elachistidae. — In: Karsholt, O. \& Razowski, J. (eds.), The Lepidoptera of Europe: 68-73. Apollo Books. Stenstrup. 380 pp.

Traugott-Olsen, E. \& Nielsen, E. S. 1977: The Elachistidae (Lepidoptera) of Fennoscandia and Denmark. - Fauna Entomol. Scand. 6: 1-299. 
